\title{
Calcinosis universalis in adult-onset dermatomyositis
}

\author{
Vera Bernardino, Ana Rodrigues, António Panarra, Nuno Riso
}

Internal Medicine Department 2, Hospital Curry Cabral, Lisboa, Portugal

\section{Correspondence to}

Dr Vera Bernardino, verarodriguesb@gmail.com

Accepted 27 July 2015

\section{DESCRIPTION}

A 67-year-old woman of African origin with dermatomyositis, diagnosed 18 years before, and dystrophic calcification known for 5 years,
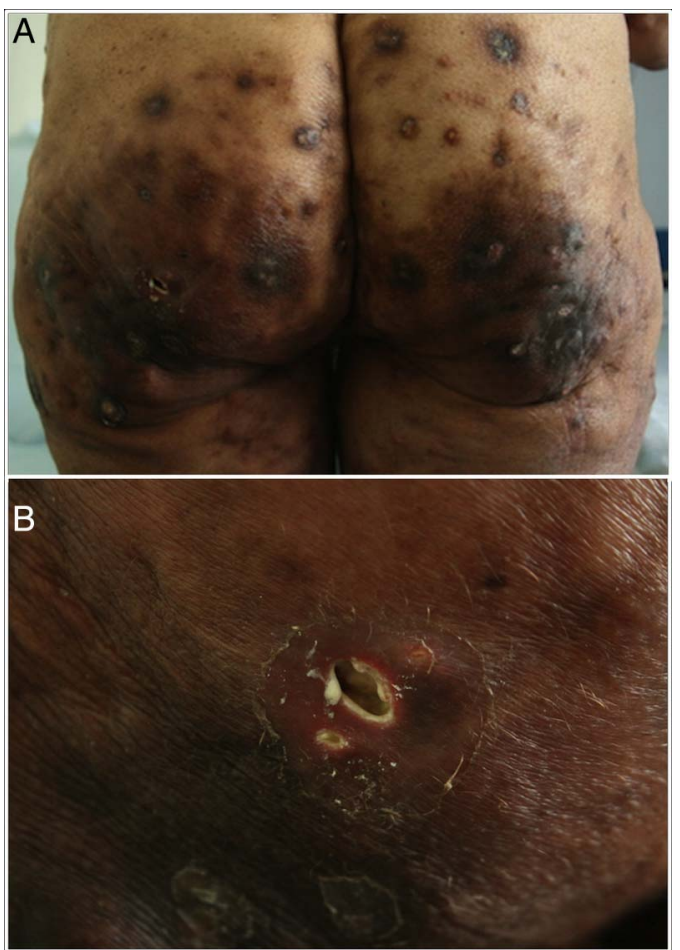

Figure 1 (A) Circular hyperpigmented lesions with palpable hard nodules in the subcutaneous tissue, corresponding to calcinosis universalis spots on both thighs; (B) Fluctuating abscess under a calcinosis spot on the left buttock. presented at follow-up consultation with fever, increased muscle weakness (scapular and pelvic chains) and gluteus pain, with spontaneous purulent drainage. She was under cyclosporine $100 \mathrm{mg}$, prednisolone $10 \mathrm{mg}$ and biphosphonates (alendronic acid and cholecalciferol). Physical examination revealed calcinosis universalis, with lesions spread over the chin, forearms, hands, abdomen, buttocks, thighs and knees (figure 1A). Her left buttock presented an inflamed fluctuating abscess (figure 1B). Proximal muscular strength test performed $3 / 5$ on the arms and $4 / 5$ on the legs.

A $5 \times 2.5 \mathrm{~cm}$ left gluteus abscess was identified over MRI and Methicillin-resistant Staphylococcus aureus was isolated, and treated with vancomycin and surgical drainage. Dermatomyositis exacerbation was controlled with increased doses of corticosteroids (figure 2).

Calcinosis cutis, first described by Virchow in 1855 , has been classified as dystrophic, metastatic, iatrogenic and idiopathic. ${ }^{1}$ Dystrophic calcinosis cutis is the most frequent type associated with dermatomyositis; when widespread, it is called 'calcinosis universalis'. Although rare in adults $(20 \%)$, these lesions are more frequent in juveniledermatomyositis (44-70\%), as the onset of calcinosis is also much earlier in the young. ${ }^{12}$ The exact physiopathology in its origin remains unclear. Dystrophic calcification is frequently painful, especially when the process involves areas close to joints or when ulceration occurs.

No treatment is uniformly effective, but surgical excision of symptomatic lesions and medical treatment with biphosphonates, diltiazem and

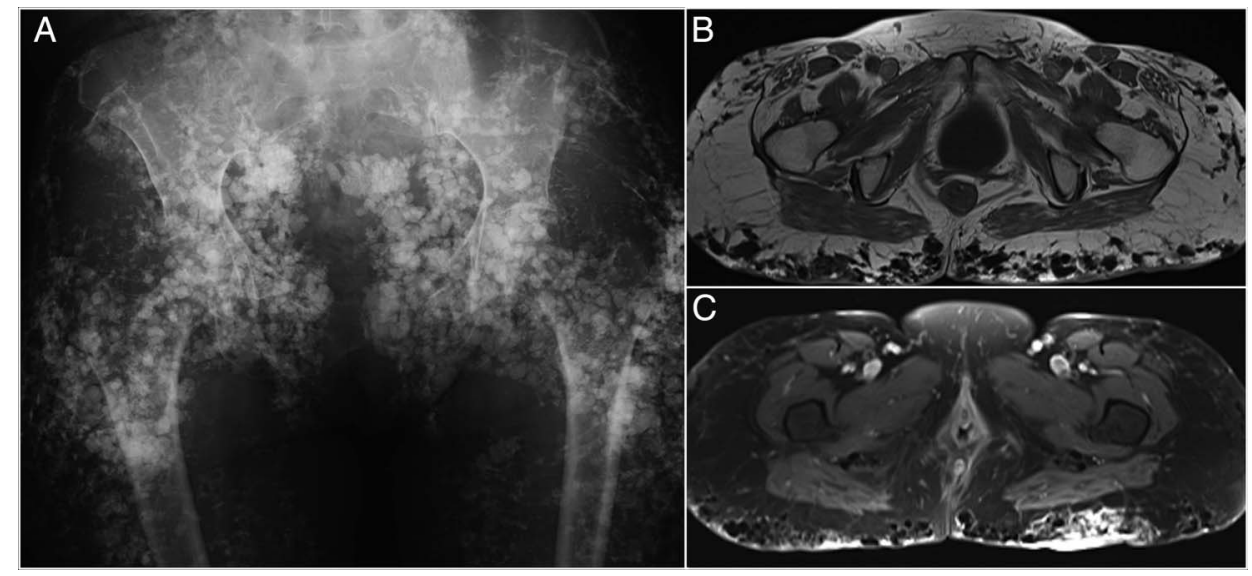

To cite: Bernardino $V$, Rodrigues $\mathrm{A}$, Panarra $\mathrm{A}$, et al. BMJ Case Rep Published online: [please include Day Month Year] doi:10.1136/bcr-2015211142
Figure 2 (A) Anteroposterior radiograph of the pelvis shows exuberant, coarse, round-shaped calcifications probably within superficial soft-tissues, hampering bone depiction. (B) Axial T1-weighted MR image reveals multiple subcutaneous, calcified nodules depicted as strongly hypointense dots. These findings are more prominent in the gluteal areas. (C) Axial fat-suppressed T1-weighted MR image after gadolinium administration shows ill-defined enhancement of the gluteal cutaneous and subcutaneous layers. On the left, the enhancement seems to circumscribe an organised lesion, which posteriorly developed into an abscess. 
aluminium hydroxide antacids seems to provide benefit for some patients. $^{23}$

\section{Learning points}

- Calcinosis universalis is rare in adult-onset dermatomyositis and further complication with subcutaneous abscess can occur.

- Immunosuppressed patients may need a more aggressive treatment, combining large-spectrum antibiotics and surgical approach.
Competing interests None declared.

Patient consent Obtained.

Provenance and peer review Not commissioned; externally peer reviewed.

\section{REFERENCES}

1 Walsh JS, Fairley JA. Calcifying disorders of the skin. J Am Dermatol 1995; 33(5 Pt 1):693-706; quiz 707-10.

2 Balin SJ, Wetter DA, Andersen LK, et al. Calcinosis cutis occurring in association with autoimmune connective tissue disease: the mayo clinic experience with 78 patients, 1996-2009. Arch Dermatol 2012;148:455-62.

3 Shinjo SK, Souza FHC. Update on treatment of calcinosis in dermatomyositis. Rev Bras Reumatol 2013:53:211-14.

Copyright 2015 BMJ Publishing Group. All rights reserved. For permission to reuse any of this content visit http://group.bmj.com/group/rights-licensing/permissions.

BMJ Case Report Fellows may re-use this article for personal use and teaching without any further permission.

Become a Fellow of BMJ Case Reports today and you can:

- Submit as many cases as you like

- Enjoy fast sympathetic peer review and rapid publication of accepted articles

- Access all the published articles

- Re-use any of the published material for personal use and teaching without further permission

For information on Institutional Fellowships contact consortiasales@bmjgroup.com

Visit casereports.bmj.com for more articles like this and to become a Fellow 